\title{
Didactic Values and Cultural Expressions of the Minangkabau Community Prohibition in Nagari Biaro Gadang
}

\author{
Hafizah $^{*}$, \\ Universitas Negeri Jakarta \\ Zuriyati, \\ Universitas Negeri Jakarta \\ Ninuk Lustyantie, \\ Universitas Negeri Jakarta \\ *) Correspondences author: Jalan Jalan Raya Perjuangan, Bekasi Utara, Jawa Barat, 17121, Indonesia; \\ e-mail: hafizah@ubharajaya.ac.id
}

\begin{abstract}
This study aims to determine the didactic value and cultural value of the expression of prohibition used by the Minangkabau community in Nagari Biaro Gadang, Agam Regency, West Sumatra. This research method used descriptive qualitative method and was carried out in three stages, such as data collection, data classification, and data analysis stages. The data was collected by observing, interviewing, recording, and taking notes on the utterances conveyed by the informants. Classification of data was done by collecting forbidden expressions. Prohibition expressions are analyzed by using a hermeneutic approach to find out the meaning of the existing prohibition expressions. Analyzing data by transcribing the results of interviews, translating into Indonesian, grouping prohibition expressions based on didactic values consisting of religious education values, moral education values, and social education values and cultural values in forbidden expressions. The result of the research shows didactic values, which consist of religious education, moral education, and social education. In addition, in the expression of the prohibition of the Minangkabau people of Nagari Biaro Gadang, cultural values are also found. The conclusion of this research is that each prohibition expression had its own didactic and cultural values.
\end{abstract}

Keywords: Prohibition Phrases, Didactic and Cultural Values, Minangkabau Cultures.

Article History: Received: 01/10/2021; Revised: 05/11/2021; Accepted: 04/12/2021; Published: 30/12/2021

How to Cite (MLA 7th): Hafizah, Zuriyati, and Ninuk Lustyantie. "Didactic Values and Cultural Expressions of the Minangkabau Community Prohibition in Nagari Biaro Gadang." Hortatori Jurnal Pendidikan Bahasa dan Sastra Indonesia 5.2 (2021): 128-134. Print/Online. Copyrights Holder: Hafizah, Zuriyati, Ninuk Lustyantie. First Publication: Hortatori Jurnal Pendidikan Bahasa dan Sastra Indonesia (2017).

\section{Introductions}

Indonesian is a pluralistic nation consisting of various ethnic groups, religions, and languages. This plurality is based on the same socio-cultural background, customs, geography, views, philosophy, and history in the nation and state. Each ethnic group has customs that contain ideas and thoughts and reflect philosophical meanings rooted in local culture (Ananda, 2015: 93). One of the regions in Indonesia that has a diversity of customs and ethnicities is West Sumatra which is famous for its Minangkabau culture. This diversity makes Minangkabau culture even more interesting because it has different customs and has been passed down by ancestors from generation to generation until now. This difference lies in the matrilineal system it adheres to (Sukmawati, 2019: 16). Minangkabau ethnic identity has contributed to the form of national culture, including through language, art, and various other aspects of tradition 
(Hasanuddin, 2015: 199). The development of Minangkabau culture today is also inseparable from the development of an increasingly advanced era with science and technology as the necessities of human life.

The development of science and technology has a positive impact on the formation of a digital technology based culture (Rustiyanti, 2014: 784), but this phenomenon also results in reduced public appreciation of traditional cultur (Bahardur, 2018: 145). The development of the times and increasingly sophisticated science also greatly affects language as a social control of society that needs to be scientifically researched because people think more logically, especially culture in Minangkabau. This social control is also expressed in the form of expressions that give an implied meaning. The expression used by the Minangkabau community is useful for providing instructions, rules, warnings, and prohibitions on which actions are permissible and which are not. Traditional expressions are part of oral folklore that functions as an educational tool and social control (Sulistyorini, 2017: 6-7). The expressions are contained in various forms of proverbs, petitih, seloka, advice, and figures of speech (Karim, 2015: 42).

Folklore as a collective culture that is spread and passed down from generation to generation and traditionally in different versions, both in oral form and examples accompanied by gestures or mnemonic devices (Mulyani, Sri, 2021: 80). This folklore is termed oral tradition because it is closely related to the spread and inheritance is carried out orally until it develops in the community. In addition, the cultural inheritance of the community internalizes culture through oral culture or commonly referred to as folklore (Fitrianita, 2018: 71). Another opinion also states that folklore is a form of traditional community culture consisting of oral folklore, partially oral folklore, and non-verbal folklore (Andheksa, 2018: 22).

Bruvand, a folklorist from the United States, explained that oral folklore is folklore that is purely oral (Endraswara, 2009: 29). The forms are folk language (slang, nicknames, titles, languages), regional expressions (proverbs and proverbs), traditional questions (riddles), folk poetry (rhymes, syair, thimbles, and proverbs), folk prose stories (mites, legends, and fairy tales), and folk songs. Partially oral folklore is a mixture of oral and non-verbal elements, such as folk belief or superstition, folk games or folk entertainment, customs, folk theater, and so on, while what is meant by non-verbal folklore is folklore whose form is material and not material (not verbal).

From the types of folklore above, the expression of prohibition is included in the category of folk belief. Modern folklorists prefer to use the term compared to using the word superstition because it implies demeaning or insulting. A similar opinion was expressed stating that the expression of prohibition is actually a hereditary inheritance from the previous generation to the next generation (Syahrir, 2016: 237). The expression of abstinence essentially instills religious values, culture, and social norms that exist in society to the next generation of the nation. So, in this study, the expression of prohibition is a part of people's beliefs.

However, even though people do not believe in the prohibition expression and consider it just a superstition, but not completely they do not believe it in another sense they are unconsciously bound by it. The phrase prohibition itself has a meaning that is closely related to the culture and didactic values of each region where it originates. Didactic values are values that are in the form of traits or things that are important and useful for humans that can be used by humans to educate and provide guidance regarding behavior of decency, intelligence, and maturity in thinking (Ismawirna, 2020: 106). This means that the prohibition contains expressions that are beneficial to society about human behavior. In line with the opinion of Ismawari, et al, another opinion states that the value of education includes the value of moral education, the value of religious education, the value of cultural education and the value of social education (Hurmatisa). Didactics values means educating or teaching or stories that can provide lessons for the readers (Laelasari \& Nurlailah, 2006: 13).

For example in the expression prohibiting Sanjo jan kalua rumah, dilarian (Don't go out at dusk, you'll be kidnapped/run away by ghosts). The didactic value contained is religious education because sunset or sunset is a time for worship for the Muslim community. Don't let the time out of the house skip the Maghrib prayer time. A ban was made by using the phrase "run by ghosts" so that people are afraid and do not leave their homes at sunset.

In addition to didactic values, there are also cultural values in the expression of prohibitions that developed in Minangkabau society. Culture will not be separated from the pattern of activities and habits carried out by the community (Prayogi, 2016: 62). The cultural values of a society are not fixed, but dynamic from one generation to the next. For example, the expression prohibiting Laki-laki Minang jan 
manikah jo padusi lua, dak basuku anak (Minang men should not marry non-Minang women, children have no ethnicity). Minangkabau society adheres to a matrilineal system, namely lineage based on maternal lineage. In a matrilineal society, children born will follow their mother's ethnicity. If the mother is Piliang, the child will also be Piliang. If there is a marriage between a Minang man and a non-Minang woman, the child born from the marriage will not have a tribe so that the lineage is blurred. Tribes for the Minangkabau people are something very important and are still preserved today. Minang male children will still be recognized by their people, but the child is not entitled to the title of sako and pusako. If there is a customary problem, it is difficult for ninik mamak to solve it.

There is research that is relevant to the research conducted entitled Kearifan Lokal Masyarakat Minangkabau dalam Ungkapan Kepercayaan Rakyat. This study describes the form, category, meaning and the function of the expression of people's beliefs in Minangkabau society (Andheska). In addition, there is also a study entitled Nilai Budaya Minangkabau dalam Ungkapan Tradisional Masyarakat Pasaman Barat which discusses traditional Minangkabau Expressions used by the people of Pasaman District, West Pasaman Regency. (Pasaman). There are ten traditional expressions used by the people of Pasaman District, namely (1) Simpang Tonang tajam sabalah; (2) Teleang kupiah Rang Mandiangin; (3) Talu rancak di labuah; (4) Barek sabalah nak Rang Talu; (5) Kalam basigi lakuang batinjau; (6) Tasingguang labiah bak kanai; (7) Nak muliya tape'i janji; (8) Nak taguah paham dikunci; (9) Bak paneh dalam baluka; (10) Bak mandi di anak sungai.

Based on several theories about educational values above, the researcher refers to the opinion expressed by Hurmatisa because opinions are easier to understand and cover all sides of human life. Thus, when connected with the existence of human life, educational values are directed to shape the human person to become a human being who has a moral, social, belief, and cultured soul

\section{Method}

This study used descriptive qualitative method. The data of this research are in the form of prohibition expressions used by the people in Nagari Biaro Gadang, Agam Regency. Research informants are three people living in Nagari Biaro Gadang with criteria aged 50-70 years, native to the area, and rarely mobilize. Determination of these criteria was carried out with the aim of obtaining a truly original prohibition expression that developed in Nagari Biaro Gadang, Agam Regency.

To analyze folklore data, it was carried out in three stages, namely 1) data collection stage, 2) data classification, and 3) data analysis. Data collection was done by observing, interviewing, recording, and taking notes on the utterances conveyed by the informants. Classification of data is done by classifying the prohibition phrases into didactic values and cultural values. Data analysis by using a hermeneutic approach to find out the meaning of the existing prohibition. Expressions transcribing the results of interviews, translating into Indonesian, analyzing folkore based on didactic values and cultural values in forbidden expressions. The didactic values analyzed include the value of moral education, the value of religious education, the value of social education, while cultural values are related to the expression of prohibition which contains elements of the culture of the Minangkabau community.

\section{Result and Discussions}

In this study, we will discuss the didactic and cultural values of the forbidden expressions used by the people of Nagari Biaro Gadang, Agam Regency using a hermeneutic approach so that younger generation still understands traditional expressions in their area.

\section{Didactic Value}

The following are the findings of the prohibition phrase containing didactic values which include the value of religious education, the value of moral education, and the value of social education.

\section{Religious Education Values}

a. Urang mangandung/suami dak buliah mambunuah binatang, mati anak waktu malahian

(Pregnant women or husbands are not allowed to kill animals, children can die when they are born) The didactic value contained is religious education because we as humans should not arbitrarily kill God's creatures. These creatures also have the right to live. Allah does not like it when we hurt His creatures. 
b. Jan manjaik sanjo, mati induak

(Don't sew the twilight, parents die)

The didactic value contained is religious education because sunset is the time to perform the Maghrib prayer and leave other activities. This prohibition implies that people should prioritize religion over the world. Man must draw closer to his creator.

c. Jan potong kuku sanjo, mati induak

(Don't cut nails at dusk, parents die)

The didactic value contained is religious education because twilight is a time to perform the Maghrib prayer and leave other activities, such as cutting nails. In addition, cutting nails at dusk is prohibited because at dusk, the lighting is reduced. If you are not careful cutting your nails, it can result in injury.

d. Jan lalok sanjo, beko panyakikan wak

(Don't sleep late, you'll get sick)

The didactic value contained is religious education because sunset is the time to perform the Maghrib prayer, recite the Koran, and perform other religious activities. Don't let the Maghrib time pass because you are still sleeping, Allah really doesn't like it.

e. Sanjo jan kalua rumah, dilarian antu

(Don't go out at dusk, you'll be kidnapped/run away by ghosts)

The didactic value contained is religious education because sunset or sunset is a time for worship for the Muslim community. Don't let the time out of the house skip the Maghrib prayer time. A ban was made by using the phrase "run by ghosts" so that people are afraid and do not leave their homes at sunset.

\section{Moral Education Values}

a. Urang manganduang jan makan di piriang sumbiang, cacat se di mato urang

(Pregnant women should not eat on a chipped/cracked plate because other people's judgments will always be bad)

The didactic value it contains is moral education about the pros and cons of eating on a cleft plate. Pregnant women should be careful when eating using a cracked/chipped plate because it can injure the user's lips. This prohibition does not only apply to pregnant women, but to everyone.

b. Urang manganduang jan duduak di lantai lakek kakak anak

(Pregnant women should not sit on the floor, clinging to the child's brother)

The didactic value contained is moral education about the good and bad of something. It is not good for pregnant women to sit on the floor because if they want to stand, it will be difficult for pregnant women to lift their bodies because of their enlarged stomach.

c. Urang manganduang jan makan di piriang gadang, gadang muluik anak

(Pregnant women should not eat using a large plate, the child's mouth will be big later)

The didactic value contained is moral education about the good and bad of eating on a big plate. Eating on a large plate will make the food look small so most people will curse why the food is given a small portion. If you use a small plate, the portion of food will look right and appropriate. This prohibition phrase also contains Minangkabau cultural values, namely that a woman must take care of herself, her children, and her family so that she must behave in the best and noble manner.

d. Urang manganduang jan makan rabuang, babulu anak

(Pregnant women should not eat bamboo shoots, they can grow hairy)

The didactic value contained is moral education about the good and bad of human behavior. Bamboo shoots are foods with a pungent odor so that pregnant women can feel nauseous when consuming them. Pregnant women should not eat bamboo shoots if they are not strong with a strong smell.

e. Urang hamil jan makan tunjang, katuban jangek anak

(Pregnant women should not eat gravel or tunjang, the amniotic fluid sticks to the child's skin)

The didactic value contained is moral education about the pros and cons of eating tunjang. Kikil or tunjang are foods that are high in cholesterol. The fat content in gravel includes saturated fat which is not good for health, especially for pregnant women. The cultural values contained are so that 
pregnant women always take care of their children and their families because in Minangkabau customs the position and role of women are very large and their existence is highly expected.

f. Jan manjaik malam, rabun mato

(Do not sew at night, eyes can be myopic)

The didactic value contained is moral education about the good and bad of human behavior. This prohibition means an educational tool for children and adolescents because when it is night it should be used to rest and not do any more activities.

g. Salasai makan jan padiaan piriang kariang, basahan priang tu, jauh rasaki

(After eating don't let the plate dry, wet the plate, far from sustenance)

The didactic value contained is moral education about the good and bad of human behavior. After eating, the dishes should be washed immediately or at least moistened with water so that the dishes do not dry out. If the dishes are dry, the leftovers will stick and harden making it difficult to wash them.

h. Jan duduak di ateh banta, bisulan beko

(Don't sit on the pillow, will get ulcers later)

The didactic value contained is moral education. Moral relates to good and bad human behavior. The meaning contained implies that the pillow is an item used for sleeping and worn on the head. Something that is worn on the head is unethical if it is also used for a seat. In principle, politeness is deemed inappropriate. Pillows can become flat if occupied continuously.

i. Jan latakan tangan di ateh kapalo, capek mati urang gaek

(Don't put your hands on your head, old people die quickly)

The didactic value contained is moral education about the good and bad of human behavior. It's not good to put your hands on your head because it characterizes someone who is lazy, doesn't want to work, and just wants to relax. This prohibition teaches young people not to be lazy, to be diligent so that what they aspire to can be achieved. In addition, putting your hands on your head is an activity that is not pleasing to the eyes of others.

j. Jan duduak di bandua, jauh rasaki

(Don't sit on the window sill, far from sustenance)

This prohibition phrase contains a moral didactic value about the good and bad of human behavior. Bandua is a window frame in the gadang house. The gadang house is quite high, so we have to be careful sitting on the window sill. If you fall you can get hurt and injured.

k. Jan kalua sadang ujan paneh, sakik beko

(Don't leave the house or travel when it's hot rain, get sick later)

The didactic value contained is moral education about the good and bad of human behavior. For Minang people, the situation when it rains mixed with heat is a situation that is not good for health because when it is hot the human body temperature will increase, whereas if it rains when it is hot, the body temperature that was previously high immediately drops and this is not good for health.

\section{Social Education Values}

a. Sadang manganduang jan nonton yang buruak-buruak, buruak lo anak

(Pregnant women should not watch bad shows, when the child is born, it will also be ugly)

The didactic value contained is social education. A mother in addition to taking care of herself, she also has to take care of the child in the womb. Pregnant women are advised to watch good, good shows so that the heart becomes happy and happy. Pregnant women should avoid pressure and stress.

b. Jan bapayuang dalam rumah, ditembak patuih

(Don't use an umbrella inside the house, you'll be hit by lightning)

The didactic value contained is social education about the good and bad of human behavior. Do not use an umbrella in the house because it can interfere with comfort. In addition, the sharp and pointed tip of the umbrella can hit the eyes and injure others.

c. Jan basiua malam-malam, masuak ula

(Don't whistle at night, the snake will get in) 
The didactic value contained is social education related to other parties. The nights are quiet times for rest. If someone whistles at night, it will make noise so that people who want to rest will be disturbed and may not be able to sleep.

d. Kalau makan abihan, jan basiso, manangih nasi

(If you eat, don't waste, cry rice)

The didactic value contained is social education for children not to leave food behind. The meaning is take enough food, don't overdo it so that it causes food to be left over. Allah/God does not like humans who waste food because there are still many people who are in need and cannot eat.

\section{Cultural Values}

The following are the cultural values contained in the expression of the prohibition of the Minangkabau community in Biaro Gadang Village, Agam Regency, West Sumatra.

1. Jan manikah sasuku sakampuang, cacat anak beko

(Not allowed to marry from one tribe and one village, children born can be disabled)

This prohibition contains cultural values that are still embraced by some Minangkabau people. This is based on the fact that marrying one ethnic group and one village will have several negative impacts, one of which is giving birth to unqualified offspring due to the same blood relationship and will experience physical disabilities and mental retardation. In addition, couples who marry in the same tribe will be ostracized by their tribe and will lose the right to hold inheritance for women. Ethnic couples will also be expelled from the village because they have embarrassed their tribe by carrying out cultural deviations in the form of customs that have been adhered to for generations.

2. Ka jadi anak daro jan pai-pai, hilang manih waktu baralek

(If you want to be a bride, don't go away, you will lose your beauty at the wedding reception)

The cultural value contained is that the bride and groom should be at home more because if they travel often, it will increase the possibility of something unwanted happening that can derail the marriage, such as an accident on the road. In Minangkabau culture, the bride and groom are not allowed to leave the house because there will be many bad things that will be caused.

3. Urang manganduang jan tagak di muko pintu, beko payah malahian

(Pregnant women should not stand in front of the door, it will be difficult to give birth)

In Minang custom, women are placed in a special position so that women are highly respected and have voting rights in their people. The privileges given must be followed by efforts to maintain the honor given, one of which is by not standing in front of the door. Standing in front of the door can prevent other people from going in and out so that other people cannot pass through the door because it prevents other people from doing their activities.

4. Harto pusako tinggi jan dijua, kualat beko

(High heirlooms cannot be sold, they can be damaged)

The cultural value contained is that the Minangkabau community has a term known as high inheritance which is supervised by a traditional leader called ninik mamak. It is this figure who determines how to manage land use rights, including the matter of selling them. Selling heritage land is not a Minangkabau custom, especially with the excuse of being extravagant.

5. Induak jan makan makanan siso anak, mada nyo beko

(Don't eat leftover food, children will be stubborn when they grow up)

Mothers in Minangkabau culture have a very special position compared to men. It would not be nice if the mother was given leftover food for the child. A child must respect, love, and cherish his mother, not even give something bad to parents.

\section{Conclusions}

Based on the research that the researcher did, it was found that the prohibition expression was still used by the people in Biaro Gadang Village, Agam Regency as an expression of belief. Users of the prohibition expression are people who are elderly, over 50 years old, native to the area, and rarely mobilize. There are many young people who do not believe in this prohibition, so it is possible that this prohibition will be eroded by the growing science and technology. The expression of prohibition is one of the semioral folklore as local wisdom in West Sumatra Province. The expression of prohibition has educational 
value and cultural value so as to provide instruction to the user and listener. The didactic value consists of the value of religious education, the value of moral education, and the value of social education, all of which lead to one thing, teaching good things.

\section{Special Gratitude}

The author would like to thank Allah SWT who has given extraordinary health blessings. Also, the authors would like to thank all those who have helped so that this research can be carried out, husband, children, parents, and the informants. Also to the Hortatory Journal which has published this article

\section{References}

Ananda, Refisa. "Kajian Fungsi Sastra Lisan Kaba Urang Tanjuang Karang Pada Pertunjukan Dendang Pauah." SEMANTIK Jurnal Ilmiah Program Studi Pendidikan Bahasa dan Sastra Indonesia 4.2 (2015): n. pag. Print.

Andheska, Harry. "Kearifan Lokal Masyarakat Minangkabau Dalam Ungkapan Kepercayaan Rakyat." BASINDO : jurnal kajian bahasa, sastra Indonesia, dan pembelajarannya 2.1 (2018): 22-28. Web.

Bahardur, Iswadi. "Kearifan Lokal Budaya Minangkabau Dalam Seni Pertunjukan Tradisional Randai." Jurnal Jentera: Jurnal Kajian Sastra 7.2 (2018): n. pag. Print.

Endraswara, Suwardi. Metodologi Penelitian Folklor: Konsep, Teori, Dan Aplikasi. yogyakarta: Media Pressindo, 2009. Print.

Fitrianita, Elsa. "Membangun Etos Dan Kearifan Lokal Melalui Foklor: Studi Kasus Foklor Di Tembalang Semarang." Endogami: Jurnal Ilmiah Kajian Antropologi 2.1 (2018): n. pag. Print.

Hasanuddin, WS. "Kearifan Lokal Dalam Tradisi Lisan Kepercayaan Rakyat Ungkapan Larangan Tentang Kehamilan, Masa Bayi, Dan Kanak-Kanak Masyarakat Minangkabau Wilayah Adat Luhak Nan Tigo." Kembara : Jurnal Keilmuan Bahasa, Sastra, dan Pengajarannya 1 (2015): 198-204. Print.

Hurmatisa. "Nilai Didaktis Dalam Cerita Putri Denda Mandalika Versi S.S.T Wisnu Sasangka Dan Hubungannya Dengan Pembelajaran Sastra Di SMA.” Jurnal Bastrindo: Bahasa dan Sastra Indonesia Universitas Mataram 1.1 (2020): n. pag. Print.

Ismawirna. "Analisis Nilai Didaktis Dalam Hikayat Ibrahim Hasan Karya Nurman Syamhas." Jurnal Metamorfosa 8.1 (2020): n. pag. Print.

Karim, Maizar. Menyelisik Sastra Melayu. yogyakarta: Histokultura, 2015. Print.

Laelasari \& Nurlailah. Kamus Istilah Sastra. Bandung: Nuansa Aulia, 2006. Print.

Mulyani, Sri, Siti Muharomah \& Memmy Dwi Jayanti. "Folklor Sendang Bulus Jimbung Klaten as Learning Moral Education." Jurnal Hortatori: Jurnal Pendidikan Bahasa dan Sastra Indonesia 5.1 (2021): n. pag. Print.

Pasaman, Kecamatan. "Ungkapan Tradisional Masyarakat Pasaman Barat Minangkabau Cultural Value At Traditional Expressions By People of Pasaman Barat." 10 709-733. Print.

Prayogi, Ryan \& Endang Danial. "Pergeseran Nilai-Nilai Budaya Pada Suku Bonai Sebagai Civic Culture Di Kecamatan Bonai Darussalam.” Jurnal Humanika 23.1 (2016): n. pag. Print.

Rustiyanti, Sri. "Seni Tradisi Randai Dengan Pembacaan Naskah Masa Kini." Seminar Nasional Riset Inovatif 2 (2014): 747-753. Print.

Sukmawati, Ellies. "Filosofi Sistem Kekerabatan Matrilineal Sebagai Perlindungan Sosial Keluarga Pada Masyarakat Minangkabau.” EMPATI: Jurnal Ilmu Kesejahteraan Sosial 8.1 (2019): 12-26. Web.

Sulistyorini, Dwi dan Eggy Fajar Andalas. Sastra Lisan: Kajian Teori Dan Penerapannya Dalam Penelitian. Malang: Madan, 2017. Print.

Syahrir, Elvina. "Ungkapan Pantang Larang Masyarakat Melayu Belantik.” Jurnal Madah: Balai Bahasa Provinsi Riau 7.2 (2016): n. pag. Print. 